\title{
ECLOGITE XENOLITH WITH EXSOLVED SANIDINE FROM THE PROTEROZOIC KURUMAN KIMBERLITE PROVINCE, NORTHERN CAPE, R.S.A.
}

\author{
Smith $^{(1)}, C . B . ;$ Ramos $^{(2)}, Z . N . ; H_{a t t o n}^{(2)}, C . J . ; H_{o r s c h}{ }^{(2)}, H$. and Damarupurshad ${ }^{(3)}, A$.
}

(1) Bernard Price Institute for Geophysica Research, U. Witwatersrand, Johannesburg 2050, R.S.A.; (2) Anglo American Research Laboratories, Box 106, Crown Mines 2025, R.S.A.; (3) Schonland Research Centre for Nuclear Sciences, U. Witwatersrand, Johannesburg 2050, R.S.A. and Geological Survey of South Africa, Silverton 0001, R.S.A.

The zero kimberlite is one of twelve known occurences of kimberlites and related rocks of the Kuruman Province, northwest Cape, South Africa. Radiometric dating has demonstrated that these bodies are 1600 to $1700 \mathrm{Ma}$ in age (Shee et al., 1989), and are thus amongst the oldest known kimberlites. They occur as small eroded pipes or dykes located on the western edge of the Kaapvaal Craton (greater than $2500 \mathrm{Ma}$ ) adjacent to the younger Kheis belt (about $1800 \mathrm{Ma}$ ) of the northern Cape Province. Zero is an oval-shaped pipe, 300m by $200 \mathrm{~m}$, intrusive into the early Proterozoic Campbell Rand dolomite of the Transvaal Supergroup. Texturally the kimberlite is a macrocrystic hypabyssal type, and is mineralogically classified as an opaque mineral-rich phlogopite calcite group I kimberlite.

The kimberlite is notable for the high mantle-derived xenolith content, but the pipe is capped by extensive calcrete, and preserved material is available only from drill core. The xenolith suite comprises equal proportions of eclogite and peridotite, the latter rocks having been studied by Shee et al. (1989) who documented evidence for a hot, perturbed geotherm. The eclogite nodules have not been studied previously in any detail. For this study a single eclogite xenolith was extracted from the Zero drill core for petrologic study, the sample being one of two initially chosen for their uncommonly large size, unusual degree of freshness, and unusual textural relations between garnet and clinopyroxene. Careful petrographic study of the speciman indicates that it is essentially a large clinopyroxene megacryst that has exsolved garnet and sanidine. Sanidine has only rarely been described as occuring in mantle eclogite (Smyth and Hatton, 1977; Smith, 1977; Ater et al., 1984), and this is the first known case where sanidine is a clear exsolution product, occuring both as discrete grains at clinopyroxene and garnet grain boundaries and as crystallographically controlled exsolutions blebs within clinopyroxene. Prior to exsolution the megacryst must have contained substantial potassium in solid solution, implying a very high pressure origin.

Average major elements analysis and standard deviations of the mineral phases (Table 1) demonstrate that they are relatively homogeneous. Garnet is relatively magnesian and calcium-poor, and in this regard is distinctive compared to previously documented sanidinebearing samples from kimberlite. The example described by Smyth and Hatton (1977) and Wohletz and Smyth (1984) is a grospydite with considerably greater Ca. Of twelve samples noted by Ater et al. (1984) from the Colorado-Wyoming kimberlites, nine are kyanite- and/or corundum-bearing and the other three are significantly more $\mathrm{Fe}$ - and $\mathrm{Ca}$-rich than the Kuruman example. Clinopyroxene in the Kuruman sample has low to moderate $\mathrm{Na}_{2} \mathrm{O}$ of $1.7 \%$. $\mathrm{Na}_{2} \mathrm{O}$ in garnet $(0.05 \%)$ and $\mathrm{K}_{2} \mathrm{O}$ in clinopyroxene $(0.03 \%)$ are low compared to type 1 diamond-bearing assemblages (McCandless and Gurney, 1989), and $\mathrm{Cr}_{2} \mathrm{O}_{3}$ is relatively high in both minerals. All of these chemical features indicate a type 2 association for the sample, as is the case for most other documented sanidine-bearing eclogites. The $\mathrm{K}_{\mathrm{b}}$ value is 3.24, and 
for an assumed pressure of $50 \mathrm{~Kb}$ the equilibration temperature is $1000^{\circ} \mathrm{C}$. This falls slightly below the peridotitic geotherm calculated by Shee et al. (1989).

Clinopyroxene and garnet are both enriched in Ce (20.2 and 9.5 ppm, respectively), and relative to $\mathrm{La}$ and $\mathrm{Nd}$ the clinopyroxene has a distinct negative $\mathrm{Ce}$ anomaly with overall LREE enrichment $(\mathrm{La} / \mathrm{Eu}=4.54)$. High $\mathrm{Ce}$ in garnet also gives a LREE enriched pattern, with HREE enrichment from Gd to Lu. Further isotopic and trace elements analysis are in progress.

Given the setting and age of the Kuruman kimberlites, data from this xenoliths and as yet unstudied additional members of the eclogite assemblage could have important bearing on the understanding of the origins and evolution of lithospheric mantle beneath the Kheis belt and marginal to the craton for which various subduction-type models have been postulated.

\section{REFERENCES}

ATER, P.C., EGGLER, D.H. and McCALLUM, M.E. (1984) Petrology and geochemistry of mantle eclogite xenoliths from Colorado-Wyoming kimberlites: recycled ocean crust? In J. Kornprobst, ed., Kimberlites II: The Mantle and Crust-Mantle Relationships, Elsevier Science Publishers, Amsterdam, 309-318.

McCANDLESS, T.E. and GURNEY, J.J. (1989) Sodium in garnet and potassium in clinopyroxene: criteria for classifying mantle eclogites. In J. Ross, Man. ed., Kimberlites and Related Rocks, Their Mantle/Crust Setting, Diamonds and Diamond Exploration, v.2, Geol. Soc. Australia Spec. Publ. 14, p. 827-832.

SHEE, S.R., BRISTOW, J.W., BELL, B.R. SMITH, C.B., ALLSOPP, H.L. and SHEE, P.B. (1989) The petrology of kimberlites, related rocks and associated matle xenoliths from the Kuruman Province, South Africa. In J. Ross, Man. ed., Kimberlites and Related Rocks, Their Composition, Occurence, Origin and Emplacement, v.1., Geol. Soc. Australia Spec. Publ. 14, p. 60-82.

SMITH, C.B. (1977) Kimberlite and mantle-derived xenoliths at Iron Moutain, Wyoming. MS thesis, Colorado State University.

SMYTH, J.R. and HATTON, C.J. (1977) A coesite-sanidine grospydite from the Roberts Victor kimberlite. Earth Planet. Sci. Lett. 34: 284-290.

WOHLETZ, K.H. and SMYTH, J.R. (1984) Origin of a Roberts Victor sanidine-coesite grospydite: thermodynamic considerations. In J. Kornprobst, ed., Kimberlites II: The Mantle and Crust-Mantle Relationships, Elsevier Science Publishers, Amsterdam, 33-42.

Table 1. Electron Microprobe Analysis of Garnet, Clinopyroxene and standard deviations for $\mathrm{N}$ analysis.

\begin{tabular}{cccc}
\hline & GAR & CPX & SAN \\
\hline $\mathrm{N}$ & 6 & 10 & 3 \\
$\mathrm{SiO}_{2}$ & $40.9+/-.3$ & $54.8+/-.03$ & $62.2+/-.3$ \\
$\mathrm{TiO}_{2}$ & $0.06+/-.02$ & $0.10+/-.02$ & - \\
$\mathrm{Al}_{2} \mathrm{O}_{3}$ & $22.8+/-.2$ & $2.94+/-.09$ & $18.4+/-.3$ \\
$\mathrm{Cr}_{2} \mathrm{O}_{3}$ & $0.25+/-.03$ & $0.15+/-.02$ & - \\
$\mathrm{FeO}$ & $16.2+/-.1$ & $4.88+/-.12$ & $0.77+/-.05$ \\
$\mathrm{MnO}$ & $0.45+/-.02$ & $0.07+/-.02$ & - \\
$\mathrm{MgO}$ & $14.9+/-.2$ & $14.5+/-.2$ & - \\
$\mathrm{CaO}$ & $4.59+/-.12$ & $20.3+/-.1$ & - \\
$\mathrm{Na} 2$ & $0.05+/-.02$ & $1.71+/-.06$ & $0.37+/-.10$ \\
$\mathrm{~K} 2 \mathrm{O}$ & & $0.03+/-.01$ & $15.6+/-.3$ \\
\hline
\end{tabular}

